\title{
Factors Affecting Agricultural Productivity among Arable Crop Farmers in Imo State, Nigeria
}

\author{
P. C. Obasi ${ }^{1}$, A. Henri-Ukoha ${ }^{1 *}$, I. S. Ukewuihe ${ }^{1}$ \\ and N. M. Chidiebere-Mark ${ }^{2}$ \\ ${ }^{1}$ Department of Agricultural Economics, Federal University of Technology, Owerri, Nigeria. \\ ${ }^{2}$ Department of Agricultural Economics, Imo State University, Owerri, Nigeria.
}

Authors' contributions

This work was carried out in collaboration between all authors. Author PCO designed the study, performed the statistical analysis, author AHU the protocol, and wrote the first draft of

the manuscript. Authors ISU and NMCM managed the analyses of the study. Author AHU managed the literature searches. All authors read and approved the final manuscript.

Research Article

Received $13^{\text {th }}$ August 2012
Accepted $23^{\text {rd }}$ January 2013
Published $1^{\text {st }}$ April 2013

\section{ABSTRACT}

The main objectives of the study were to examine and identify the factors that affect agricultural productivity in Imo State, Nigeria. The method of proportionate random sampling technique was used in selecting a sample of 99 farmers who were interviewed using validated, structured questionnaire. Primary data collected were analyzed using frequencies, means, and the Ordinary Least Squares multiple regression analysis technique. The results of the analysis show that the marginal value products estimated for farmland, planting materials, chemical fertilizer and labour are 0.0654, 0.0615, 0.0871 and 0.0831 respectively. Yam/cassava/maize/vegetable/melon combination was identified as the main crop combination practiced by the farmers in the state. Analysis of resource use efficiency shows that the farmers are highly efficient in the use of planting materials but highly inefficient in the use of land and chemical fertilizer. The results of the multiple linear regression analysis on the determinants of agricultural productivity show that age, level of education, years of farming experience, farm size, extension contact, fertilizer use, planting materials and labour use are the main determinants of agricultural productivity in the state. It is recommended that extension agents should teach farmers to use the right quality and 
quantity of chemical fertilizers, and the use of high yielding planting materials to enhance farmers' productivity.

Keywords: Mixed cropping; arable crop farmers; resource use efficiency; productivity.

\section{INTRODUCTION}

Nigeria has not been able to attain self sufficiency in food production due to lack of mechanization and the small scale nature of production. The country is among the countries in Sub Saharan Africa that experience significant food shortages as over $40 \%$ of the country's population is estimated to be food insecure [1]. The food shortage problem is indicative of the high food import bills, consistent rise in domestic food price, high annual growth rates of food demand when compared with food supply and nutritional problems among others [2]. The problem of food shortages and insecurity is exacerbated when we consider the fact that food production in Nigeria is in the hands of small scale farmers who practice mixed cropping system and cultivate between 1-2 hectares of farm land which are usually scattered over a wide area [2,3]. In addition, the productivity of these farmers is often affected by factors such as age, cropping patterns, years of farming experience, and lack of access to credit which tend to impact negatively on productivity and efficiency. According to FACU [4]; FDA [5]; FDA [6], despite all human and material resources devoted to Nigerian agriculture, the productive efficiency of farmers for most crops still fall below $60 \%$. The inefficiency problem is attributed to factors such as use of low input technologies, lack of knowledge of high input technologies and poor farm management skills, poor extension services, unavailability and high cost of inputs $[7,8,9]$. Previous studies on efficiency of resource utilization and productivity $[10,11,12,13,14]$ showed that there are wide variations in the levels of productivity and productive efficiency for the major food crops, and the levels are far from the optimum. This indicates therefore that ample opportunities exist for the farmers to increase their productivity and productive efficiency. It is against this backdrop that the study examined agricultural production in Imo State with the main objective of determining and isolating the factors that affect farmers' productivity in the area. The specific objectives are to examine the socio- economic characteristics of arable crop farmers in Imo State, identify the crop mixtures practiced by these farmers, ascertain the reasons for the practice of the cropping system, evaluate the production efficiency of the farmers in the state, and determine and isolate the factors that affect agricultural productivity of the farmers in the state.

\section{MATERIALS AND METHODS}

\subsection{Study Location}

The study was carried out in Imo State, Nigeria. The State lies within latitudes $5^{\circ} 40^{1}$ and $7^{\circ} 5^{1}$ North and longitudes $6^{\circ}=35^{1}$ and $8^{\circ}=30^{1}$ east. The State covers a land area of $7,480 \mathrm{~km}^{2}$ with a population of 3,939,899 people [15]. Five distinct soil types have been identified in the state and these include lithosols, alluvial soil, ferralithic soils, medium fine alfisols and clayey hydromorphic soils. The vegetation of the area is tropical rainforest which experiences soil erosion and degradation. The soil is slightly acidic with a pH of 5.0 to 5.5 [16]. The state is characterized by tropical climate with high humidity and temperatures that range between $1500 \mathrm{~mm}$ to $2300 \mathrm{~mm}$ and $34^{\circ} \mathrm{C}$ to $37^{\circ} \mathrm{C}$ respectively [16]. The state is divided into three main agricultural zones, namely Owerri, Okigwe and Orlu. It is further divided into 27 local 
government councils. The main crops grown in the area include cassava, cocoyam, yam, maize, melon and vegetables (green, fluted pumpkin, water-leaf, bitter leaf, etc). The livestocks reared include; sheep, goats, fishes, pigs and poultry.

\subsection{Sampling Procedure and Data Collection}

The method of proportionate random sampling technique was used in selecting the sample communities. This method was considered appropriate because the 3 agricultural zones in the state do not have equal number of local government areas (LGA's). Five local government areas were randomly selected from the Owerri agricultural zone. These LGA's are Ikeduru, Mbaitolu, Ngor Okpala, Oguta and Aboh Mbaise. From each of these LGA's, 3 rural communities were randomly chosen, thus giving a total of 15 rural communities. Furthermore, 3 villages were randomly selected from each of these rural communities. Finally one (1) arable crop farmer was randomly selected from each of the 45 rural villages. This gave a total of 45 farmers from the Owerri agricultural zone.

The same procedure was adopted in selecting the sample farmers from the Orlu agricultural zone. In Orlu zone, 4 LGA's were randomly selected. These LGA's are Orsu, Njaba, Ideato North and Nwangele. From each of these 4 LGA's, 3 rural communities were randomly chosen. Thereafter, 3 villages were randomly selected from each of the 12 rural communities, thus giving a total of 36 rural villages. Then, from each of these 36 rural villages, one (1) arable crop farmer was randomly chosen, thus giving a sample of 36 farmers from the Orlu agricultural zone.

Similarly, 3 LGA's were selected from the Okigwe agricultural zone. These LGA's are Ehime Mbano, Obowo and Ihitte Uboma. From each of these LGA's, 3 rural communities were randomly chosen, thus giving a total of 9 rural communities. Then, 2 rural villages were randomly selected from each of these communities. Finally, one (1) arable crop farmer was randomly selected from each of the 18 rural villages, thus giving a sample of 18 farmers from the Okigwe agricultural zone. These gave a total of 99 respondents. The sampling frame comprised the list of all registered arable crop farmers obtained from the Imo State Agricultural Development Programme (ADP). The primary data used for the study were collected from the field using structured validated questionnaire. Major variables on which data were collected include age, educational level, years of farming experience, land area cultivated, expenditure on planting materials, household size, labour input used, extension contact, output, gender of the farmer, marital status, crop mixtures practiced, and expenditure on chemical fertilizer used. Data on costs were also collected on crops such as yam, cassava, maize, cocoyam, melon, vegetables. Data collected were analyzed using frequencies, means, and the Ordinary Least Squares multiple regression analysis. In line with the use of the Ordinary Least Squares regression (OLSR) technique, four functional forms (Linear, Double-log, Exponential and Semi-log) were fitted to the data. The equation that gave the 'best fit' was then selected as the lead equation based on conformity with a priori expectations(expected signs of the estimators, the magnitude of the coefficient of multiple determination $\left(R^{2}\right)$, and the statistical significance of the parameter estimates) [17]. However, since the Linear and Semi-log functions cannot be compared directly with the Double-log and Exponential functions on account of the specification of the dependent variable in both the Double-log and Exponential functions [18], the Linear and Semi-log functions were transformed to make them directly comparable with the Double-log and Exponential functional forms. 
The dependent variable in the Linear and Semi-log forms were transformed thus:

$$
Y_{t}^{*}=C Y_{t}
$$

Where $Y_{t}^{*}=$ transformed dependent variable

$C=$ reciprocal of the geometric mean of $Y$ values

$\mathrm{Y}_{\mathrm{t}}=$ original values of $\mathrm{Y}$ in period $\mathrm{t}$

The explicit forms of the functions are given as:

(a) Linear:

$$
Y=b_{0}+b_{1} X_{1}+b_{2} X_{2}+\ldots+b_{9} X_{9}+e
$$

(b) Cobb-Douglas: $\operatorname{LnY}=\operatorname{Lnb}_{0}+b_{1} \operatorname{LnX} X_{1}+b_{2} \operatorname{Ln} X_{2}+\ldots+b_{9} \operatorname{Ln} X_{9}$

(c) Exponential: $\quad \operatorname{LnY}=b_{0}+b_{1} X_{1}+b_{2} X_{2}+\ldots+b_{9} X_{9}$

(d)

Semi-Log:

$$
Y=b_{0}+b_{1} L n X_{1}+b_{2} L_{n} X_{2}+\ldots+b_{9} L_{n} X_{9}
$$

Where

$$
\begin{aligned}
& \mathrm{Y}=\text { gross value of output }(\mathrm{N}) \\
& \mathrm{X}_{1} \quad=\text { age of farmer (years) } \\
& \mathrm{X}_{2} \quad=\text { educational level (years) } \\
& \mathrm{X}_{3} \quad=\text { farming experience (years) } \\
& X_{4} \quad=\text { farm size (hectare) } \\
& \mathrm{X}_{5} \quad=\text { household size (number of persons) } \\
& \mathrm{X}_{6} \quad=\text { extension contact (number of visits) } \\
& \mathrm{X}_{7} \quad=\text { expenditure on planting materials }(\mathrm{N}) \\
& \mathrm{X}_{8} \quad=\text { expenditure on chemical fertilizer ( } \mathrm{N} \text { ) } \\
& \mathrm{X}_{9} \quad=\text { labour input (man-days). } \\
& \mathrm{e} \quad=\text { random error term } \\
& \mathrm{b}_{0}, \mathrm{~b}_{1}, \ldots, \mathrm{b}_{9} \quad=\text { regression coefficients } \\
& \mathrm{Ln} \quad=\text { natural logarithm. }
\end{aligned}
$$

\section{RESULTS AND DISCUSSION}

\subsection{Socio-Economic Characteristics of Farmers}

Table 1 shows the frequency distribution of farmers according to age and number of years spent in school. The table suggests that $(42.42 \%)$ of the respondents are within the age bracket of 51 to 60 years. The mean age of the farmers was found to be 56 years. This age might not be appropriate for strenuous farm activities like weeding, planting and heaping [19], and as a result may negatively affect production by leading to technical inefficiency. The table also shows that $(36.36 \%)$ of the farmers spent between 16 to 20 years in school. On the average, a farmer spent 12.6years in school. It is expected that education would aid the farmers to interpret instructions on the use of agrochemicals, adopt modern agricultural technologies and take wise decisions on farming operations. The level of education of a farmer not only increases his farm productivity but also enhances his ability to understand and evaluate new production techniques [19,20,21,22]. 
Table 1. Frequency distribution of farmers according to age and number of years spent in school

\begin{tabular}{lll}
\hline Socio-economic characteristics & Frequency $(\boldsymbol{f})$ & Percentage $(\%)$ \\
\hline Age (years) & 1 & \\
$31-40$ & 24 & 1.01 \\
$41-50$ & 42 & 24.24 \\
$51-60$ & 32 & 42.42 \\
$61-70$ & & 32.32 \\
Mean age = 56 years & & \\
Number of years spent in school (years) & \\
$0-5$ & 35 & 4.04 \\
$6-10$ & 24 & 35.35 \\
$11-15$ & 36 & 24.24 \\
$16-20$ & & 36.36 \\
Mean years of schooling =12.6 years & & \\
$\mathrm{n}=99$ & & \\
\hline
\end{tabular}

\section{Source: Field survey data, 2010.}

Table 2 shows the frequency distribution of farmers according to years of farming experience, and size of farm holding. The table shows that $(45.5 \%)$ of the farmers had between 11 to 20 years of farming experience, while (26.26\%) had between 41 to 50 years of farming experience. The mean years of farming experience was 28 years. With regard to size of farm holding, the table shows that $(77.7 \%)$ of the respondents cultivated between 0.9 to 1.7 hectares of farm land. Mean farm size was 1.4 hectares. This means that majority of the farmers operating in the area are small scale (cultivating less than 3.0 hectares of land). Small holdings can lead to more intensive and efficient use of land resources if properly utilized [3].

Table 2. Frequency distribution of farmers according to years of Farming experience and size of farm holding

\begin{tabular}{lll}
\hline Socio-economic characteristics & Frequency $(\boldsymbol{f})$ & Percentage $(\%)$ \\
\hline Farming Experience (years) & 7 & 7.07 \\
$1-10$ & 45 & 45.45 \\
$11-20$ & 4 & 4.04 \\
$21-30$ & 11 & 11.11 \\
$31-40$ & 26 & 26.26 \\
$41-50$ & 6 & 6.06 \\
$>50$ & & \\
Mean years of farming experience = 28 years & & \\
Farm Size $(\mathrm{Ha})$ & 5 & 5.1 \\
$\leq 0.8$ & 77 & 77.7 \\
$0.9-1.7$ & 17 & 17.2 \\
$1.8-2.6$ & & \\
Mean farm size $=1.4 \mathrm{Ha}$ & & \\
$\mathrm{n}=99$ & Source: Field survey data, 2010. \\
\hline
\end{tabular}

Source: Field survey data, 2010.

Table 3 shows the frequency distribution of farmers according to household size, gender, marital status and occupation. The table shows majority $(86.9 \%)$ of the farmers' have household size ranging between 6 and 10 persons. The mean household size was 8 
persons. With respect to gender and marital status of farmers, the table also shows that $(52.5 \%), 47.5 \%$ are females and males respectively, while $100 \%$ of them are married. The table also shows that $(54.4 \%)$ of the farmers had farming as their main occupation, while $45.5 \%$ of the farmers had other occupations (such as civil service, trading, processing of agricultural produces, brick laying, etc) as their main occupation. This suggests that most of the farmers combined occupations to complement their earnings.

Table 3. Distribution of farmers according to household size, gender, marital status and occupation

\begin{tabular}{lll}
\hline Socio-economic characteristics & Frequency $(\boldsymbol{f})$ & Percentage (\%) \\
\hline Household Size (persons) & 2 & 2.0 \\
$1-5$ & 86 & 86.9 \\
$6-10$ & 11 & 11.1 \\
$11-15$ & & \\
Mean household size = 8 persons & 47 & 47.5 \\
Gender & 52 & 52.5 \\
Male & & \\
Female & 83 & 83.8 \\
Marital Status & 0 & 0 \\
Married & 0 & 0 \\
Single & 14 & 14.1 \\
Divorced & 02 & 2.1 \\
Widow & & \\
Widower & 54 & 54.5 \\
Occupation & 45 & 45.5 \\
Farming & & \\
Non-farming & & \\
$\mathrm{n}=99$ & & \\
\hline
\end{tabular}

Source: Field survey data, 2010.

\subsection{Identification of Crop Mixtures Practiced by Farmers}

Table 4 shows the frequency distribution of farmers according to crop mixtures practiced. The table shows that mixed cropping is the common cropping system practiced in the state. Maize was included in all the crop mixtures practiced, $99 \%$ of the crop combinations had cassava, while $72 \%$ had yam. According to lbeawuchi et al. [23], these crops dominate most crop combinations because of the position they occupy in the daily life of people of the state. Yam/cassava/maize/vegetable/melon combination was identified as the main (100\%) crop combination practiced by farmers in the state. This could be attributed to the relative importance of the crops involved. Cassava is a major source of cheap calories and can be processed and consumed in various forms. Its usage as a source of ethanol for fuel, energy in animal feeds and starch for industry is increasing [24]. Vegetable is a good source of minerals and vitamins. Melon which is used to prepare delicious soup is a good source of vegetable oil and contains some levels of protein. Maize is a source of carbohydrate and protein. It also serves as feed for animals. Yam is a good source of carbohydrate. Second in the order (18.2\%) was cassava/yam/maize/melon combination, which is similar to the one above. The difference in the two crop mixtures lies in the fact that yam was planted before cassava and vegetable was involved in the first. The third placed combination (9.1\%) was maize/cassava/vegetables. However, maize/yam/cassava/melon, yam/maize, maize/cassava, cassava/maize/vegetable/cocoyam/melon/local

beans, 
cassava/maize/vegetable/cocoyam/local beans, maize/cassava and cassava/yam/maize/ vegetable/melon combinations were the least cropping combinations among the farmers. The above findings contradict the findings of Odurukwe and Ikeorgu [25], who found that yam/maize/cassava intercrop, was the most dominant crop mixture in the southeastern agricultural zone of Nigeria, as none of the respondents adopted the pattern. This could suggest that, crop combinations practiced by farmers may vary with time. Since yam/cassava/maize/vegetable /melon combination was identified as the major crop mixture practiced by the farmers, it was used for further analysis of the data.

Table 4. Frequency distribution of farmers according to crop mixtures practiced

\begin{tabular}{|c|c|c|c|c|c|}
\hline Crop mixture & $\begin{array}{l}\text { Frequency } \\
\text { (f) }\end{array}$ & $\begin{array}{l}\text { Percentage } \\
(\%)\end{array}$ & Crop mixture & $\begin{array}{l}\text { Frequency } \\
\text { (f) }\end{array}$ & $\begin{array}{l}\text { Percentage } \\
(\%)\end{array}$ \\
\hline $\mathrm{Y} / \mathrm{C} / \mathrm{M} / \mathrm{V} / \mathrm{ML}$ & 99 & 100 & $\mathrm{C} / \mathrm{M} / \mathrm{V} / \mathrm{ML}$ & 3 & 3.0 \\
\hline $\mathrm{C} / \mathrm{Y} / \mathrm{M} / \mathrm{ML}$ & 18 & 18.2 & $\mathrm{C} / \mathrm{M} / \mathrm{V} / \mathrm{ML} / \mathrm{LB}$ & 2 & 2.0 \\
\hline $\mathrm{M} / \mathrm{C} / \mathrm{V}$ & 9 & 9.1 & $\mathrm{Y} / \mathrm{C} / \mathrm{M} / \mathrm{V} / \mathrm{CY}$ & 2 & 2.0 \\
\hline $\mathrm{C} / \mathrm{M} / \mathrm{V} / \mathrm{CY} / \mathrm{ML}$ & 7 & 7.1 & $\mathrm{C} / \mathrm{M} / \mathrm{CY} / \mathrm{V} / \mathrm{Y} / \mathrm{ML}$ & 2 & 2.0 \\
\hline $\mathrm{Y} / \mathrm{C} / \mathrm{V} / \mathrm{M} / \mathrm{CY} / \mathrm{ML}$ & 6 & 6.1 & $\mathrm{M} / \mathrm{C}$ & 1 & 1.0 \\
\hline $\mathrm{C} / \mathrm{M}$ & 5 & 5.1 & $\mathrm{C} / \mathrm{Y} / \mathrm{M} / \mathrm{V} / \mathrm{ML}$ & 1 & 1.0 \\
\hline $\mathrm{M} / \mathrm{Y} / \mathrm{C}$ & 5 & 5.1 & $\mathrm{C} / \mathrm{M} / \mathrm{V} / \mathrm{CY} / \mathrm{LB}$ & 1 & 1.0 \\
\hline $\mathrm{C} / \mathrm{Y} / \mathrm{M} / \mathrm{V} / \mathrm{CY}$ & 4 & 4.0 & C/M/V/CY/ML/LB & 1 & 1.0 \\
\hline $\mathrm{Y} / \mathrm{C} / \mathrm{M} / \mathrm{V} / \mathrm{ML}$ & 4 & 4.0 & $\mathrm{Y} / \mathrm{M}$ & 1 & 1.0 \\
\hline $\begin{array}{l}\mathrm{Y} / \mathrm{C} / \mathrm{M} / \mathrm{V} / \mathrm{LB} \\
\mathrm{n}=99\end{array}$ & 3 & 3.0 & $\mathrm{M} / \mathrm{Y} / \mathrm{C} / \mathrm{ML}$ & 1 & 1.0 \\
\hline
\end{tabular}

\subsection{Reasons for Practicing Mixed Cropping System}

Table 5 shows the frequency distribution of farmers according to reasons for practicing mixed cropping system. The table shows that household food security was the prevailing reason for mixed cropping in the study area. This confirms the findings of Fawole and Oladele [2] as the major reason for having more than one crop on a piece of land at the same time. Ensuring increased and steady family income was the second major reason for adopting mixed cropping system in the area. The results further show that $60.6 \%$ of the respondents practice mixed cropping for the purposes of increased and steady family income. This is understandable considering the fact that every family needs increased and steady income to improve her standard of living. Reduction of production cost came next in the order of importance and closely related to the one above (as it will increase net profit or productivity of the farmers). Optimal utilization of production resources came fourth in the ranking. This suggests that, farmers believed that resources such as fertilizer, labor, time etc could be better utilized or evenly distributed if more than one crop were combined at the same time on a piece of land. Normally, shallow feeders are combined with deep feeders, or early maturing crops (example maize) with late maturing crop such as cassava. Legumes (such as beans, melon, and groundnut) help to maintain soil fertility by covering the soil and fixing nitrogen to the soil. Early maturing crops could generally serve as manure to later crops. However, while other reasons occupied different positions in the table, ecological and climatic reasons ranked last with $5.1 \%$ response. This implies that ecological and climatic conditions were minor reasons for adopting mixed cropping system in the state. 
Table 5. Distribution of farmers according to reasons for practicing mixed cropping system

\begin{tabular}{lll}
\hline Reasons for practicing mixed cropping system & $\mathbf{( f )}^{\star}$ & Percentage (\%) $^{\star}$ \\
\hline Food security & 74 & 74.7 \\
Increased and steady family income & 60 & 60.6 \\
Reduction of production cost & 49 & 49.5 \\
Optimal utilization of production resources & 45 & 45.5 \\
Security of farm land & 40 & 40.4 \\
Easy supervision and maintenance & 34 & 34.3 \\
A traditional technology or method & 24 & 24.2 \\
Nutritional balance or enhancement & 20 & 20.2 \\
Measure against total crop failure & 18 & 18.2 \\
Measure of pests and disease control & 14 & 14.1 \\
Soil conservation and weeds control & 7 & 7.1 \\
Ecological and climatic conditions n $=99$ & 5 & 5.1 \\
\hline
\end{tabular}

Source: Field survey data, 2010.

\subsection{Production Efficiency of Farmers}

Table 6 shows the analysis of resource use efficiency of the farmers. Efficiency indices in the table were calculated as the ratios of marginal value product (MVP) to marginal factor cost (MFC) using the double log function as the lead equation. The efficiency indices suggest that farm land $\left(X_{4}\right)$, planting materials $\left(X_{7}\right)$ and chemical fertilizer $\left(X_{8}\right)$ were under utilized by the farmers. This implies that positive adjustments could be made to their present values if efficiency in their utilization is the objective. On the other hand, the efficiency index $(0.086)$ calculated for labor suggests that it was over utilized. This implies that, the level at which labour is used presently should be reduced to achieve efficiency. Relatively, planting materials (with efficiency index of 1.043) was the most efficiently utilized resource. Farm size was the most inefficiently utilized resource with efficiency index of 3.528.

Table 6. Analysis of resource use efficiency of the farmers

\begin{tabular}{lllll}
\hline Items of value & \multicolumn{3}{l}{ Resources } & \\
\cline { 2 - 5 } & Farm size & Planting materials & Fertilizer & Labor \\
\hline APP & $2,423.45$ & 16.10 & 848.21 & 3.85 \\
MPP & 158.49 & 0.99 & 73.88 & 0.32 \\
MVP & 21,168 & 132.22 & 9,867 & 42.74 \\
MFC & $6000 /$ ha & $126.71 / \mathrm{kg}$ & $3,289 / \mathrm{bag}$ & $495 / \mathrm{md}$ \\
Efficiency index & 3.528 & 1.043 & 3.0 & 0.086 \\
\hline \multicolumn{5}{r}{ Md = man-day } \\
\end{tabular}




\subsection{Determinants of Agricultural Productivity in the Study Area}

Table 7 shows the result of the multiple regression analysis on the determinants of agricultural productivity of arable crop farmers in Imo-state. Based on the magnitude of the coefficient of multiple determination $\left(R^{2}\right)$, and the size and signs of the parameter estimates, as well as their statistical significance [17], the double log function was chosen as the lead equation and used for further analysis of the data. The coefficient of multiple determination $\left(R^{2}\right)$ of 0.87 implies that $87 \%$ of the variations in productivity $(Z)$ are explained by the joint action of the independent variables. The analysis shows that educational level $\left(X_{2}\right)$, farming experience $\left(X_{3}\right)$, farm size $\left(X_{4}\right)$, extension contact $\left(X_{6}\right)$ and labor $\left(X_{9}\right)$ had positive and significant relationships with productivity. This suggests that total factor productivity will increase significantly if these factors are increased above their present levels of use. It is expected that productivity will increase if more experienced and educated farmers cultivate greater hectares of farm land. On the other hand, age $\left(X_{1}\right)$, planting materials $\left(X_{7}\right)$ and chemical fertilizer $\left(X_{8}\right)$ are inversely related to productivity. This suggests that if these factors are increased above their present levels, productivity will decrease significantly. This is expected if aged and weak farmers are involved in agricultural production. Also, coefficient of household size was found to be negative and statistically insignificant. This suggests that the negative relationship between productivity and household size could be attributed to error. However, productivity tends to decrease if household size adds more to the production cost than it adds to the value of output. 
Table 7. Determinants of agricultural productivity in Imo-state

\begin{tabular}{|c|c|c|c|c|c|c|c|c|}
\hline & Linear & & Exponential & & Semi-log & & Double- & \\
\hline $\begin{array}{l}\text { Explanatory } \\
\text { variables }\end{array}$ & Coeff. & t-ratios & Coeff. & t-ratios & Coeff. & t-ratios & Coeff. & t-ratios \\
\hline Age $\left(X_{1}\right)$ & -3.0841 & -1.0923 & -2.9138 & -1.1193 & -0.0718 & $-3.4686^{\star *}$ & -0.0073 & $-2.5172^{\star \star}$ \\
\hline Education level $\left(X_{2}\right)$ & 10.9217 & 1.1981 & 1.5093 & 1.0117 & 0.0813 & $2.5486^{* \star}$ & 0.0092 & 1.0824 \\
\hline Farming exp. $\left(X_{3}\right)$ & 9.0829 & $2.8811^{* *}$ & 2.6779 & 1.0701 & 0.0792 & $2.9887^{* *}$ & 0.0071 & $2.4483^{* *}$ \\
\hline Farm size $\left(X_{4}\right)$ & 7.2217 & 1.1299 & 3.1095 & $2.9299^{* *}$ & 0.0604 & $2.7834^{* *}$ & 0.0074 & 1.0882 \\
\hline Household size $\left(X_{5}\right)$ & -3.0213 & $-2.1699^{*}$ & -3.1943 & -1.3341 & -0.0529 & -1.0644 & -0.0042 & -1.0769 \\
\hline Extension visit $\left(\mathrm{X}_{6}\right)$ & 10.3392 & 1.1324 & 2.0841 & $2.9321^{* *}$ & 0.0849 & $3.9124^{* *}$ & 0.0055 & 1.1225 \\
\hline Planting material $\left(\mathrm{X}_{7}\right)$ & -6.5911 & $-3.1668^{* *}$ & -1.3391 & -1.1097 & -0.0339 & $-3.2913^{\star *}$ & 0.0073 & $-3.0417^{* *}$ \\
\hline Fertilizer $\left(\mathrm{X}_{8}\right)$ & -6.8913 & -1.2114 & -1.0667 & -1.0982 & -0.0821 & $-3.3374^{\star *}$ & -0.0078 & -1.1304 \\
\hline Labour $\left(X_{9}\right)$ & 9.2813 & 1.1303 & 1.5912 & 1.2965 & 0.0518 & $3.7266^{* *}$ & 0.0057 & $2.7143^{\star *}$ \\
\hline Constant & 217.0928 & & 173.1467 & & 113.5006 & & 89.4728 & \\
\hline Std. error of est. & 16.1153 & & 12.9814 & & 0.0337 & & 0.0934 & \\
\hline $\mathrm{R}^{2}$ & 0.4962 & & 0.4022 & & 0.8651 & & 0.6025 & \\
\hline F-value & 9.8452 & & 6.7911 & & 64.0815 & & 15.2146 & \\
\hline $\mathrm{N}$ & 99 & & 99 & & 99 & & 99 & \\
\hline
\end{tabular}

$\left(^{* *}\right)=$ significant at $1 \%,\left({ }^{*}\right)=$ significant at $5 \%$

Source: Field survey data, 2010 


\section{CONCLUSION}

Based on the results of the analysis, we conclude that agricultural productivity will increase in the area if the level used of factors such as farm size, labour input, chemical fertilizer, and planting materials is increased. Similarly, productivity will also increase if there are increased levels of extension contact, and if farmers with higher educational level and greater years of farming experience engage in agriculture.

\section{RECOMMENDATION}

Based on the findings of this research study, it is recommended that extension agents should teach farmers to use the right quality and quantity of chemical fertilizers, and the use of high yielding planting materials to enhance agricultural productivity in the area. Apart from using the extension agents to teach the farmers the use of high yielding input varieties, it is also recommended that the input delivery system should be improved upon to make the inputs available at the right time and at affordable prices too.

\section{COMPETING INTERESTS}

Authors have declared that no competing interests exist.

\section{REFERENCES}

1. Mariya-Dixton B, Akinleye E, Oguntona S, Nokoe R, Sanus A, Hariss E. Nigeria food consumption and nutrition survey (2001-2003 Summary). International Institute for Tropical Agriculture. (IITA) Ibadan; 2004.

2. Fawole OP, Oladele IO. Sustainable food crop production through multiple cropping patterns among farmers in South-West Nigeria. Journal of Human Ecology. 2007;21(4):245-249.

3. Obasi PC. Farm size- productivity relationship among arable crops farmers in Imo State, Nigeria. International Journal of Agriculture and Rural Development. 2007;9(1):91-99.

4. Federal Agricultural Coordinating Unit (FACU). Proceeding on the $4^{\text {th }}$ annual national farming systems. Research and Extension Workshop. Federal Agricultural Coordinating Unit Reports, Ibadan; 1992.

5. Federal Department of Agriculture (FDA). Food Security and Nigeria agriculture, water resources and rural development. Federal Department of Agriculture, Abuja, Nigeria; 1993.

6. Federal Department of Agriculture (FDA). Federal Department of Agriculture; Federal Ministry of Agriculture Reports. Abuja, Nigeria; 1995.

7. Obasi PC. Application of translog fuction to productivity estimation in Imo State, Nigeria. International Journal of Agriculture and Rural Development (IJARD). 2005;6:26-33.

8. Anyanwu SO, Obasi PC. Comparative Analysis of Land Productivities in low and High External Input Technology Agriculture in Imo State, Nigeria. Acta Agronomica Nigeriana. 2010a;10(1):15-21. June.

9. Anyanwu SO, Obasi PC. Comparative analysis of aggregate agricultural productivity between low and high external input technology farms in Nigeria. African Journal of Biotechnology. 2010b;9(34):5530-5534. August. 
10. Moses J, Adebayo EF. Efficiency of factors determining rain fed rice production in Ganye LGA, Adamawa state. Journal of Sustainable Development in Agricultures and Environment. 2006;3:20-30.

11. Oluwatosin FM. Resource use efficiency among Maize Grower Households in Ekiti state, Nigeria. Agricultural Journal. 2006;3(2):134-141.

12. Iheanacho AC, Olukosi JO, Ogungbile AO. Economic efficiency of resource use in Millet-Based cropping system in Borno-State, Nigeria. Nigeria Journal of Tropical Agriculture. 2000;2:18-30.

13. Ike CP, Ogba A. Resource use efficiency by cassava women farmers: Evidence from Enugu state, Nigeria. Proceeding of $39^{\text {th }}$ Conference of the Agri. Society of Nigeria, Benin, October. 2004;9-13.

14. Onyenweaku CE, Obasi PC, Anyanwu SO. Production relationships among compound and non - compound farms in Imo State, Nigeria. Journal of Applied Science in Southern Africa. 1996;2(1):31-36. University of Zimbabwe, Mount Pleasant Harare.

15. National Population Commission (NPC). National Population Census figures, Abuja. Nigeria; 2006.

16. Imo State Ministry of Agriculture and Natural Resources (ISMANR). Owerri. Imo State, Nigeria; 1986.

17. Olayide OS, Heady EO. Introduction to agricultural production economics. Ibadan University Press. 1982;24-109.

18. Olayemi JK, Olayide SO. Elements of Applied Econometrics, $1^{\text {st }}$ ed., Card Publisher, Ibadan University Press, Ibadan Nigeria. 1981;175-177.

19. Olomola AS. Agribusiness Credit in Nigeria: Dimensions of Institutional and Policy Deficiencies. Paper presented at the Third National Conference of the Farm Management Association of Nigeria, ARMTI. Ilorin; 1986.

20. Noor, A. Education and Basic Human Needs. World Bank Staff Working Paper, No. 450, Washington, D.C.; U.S.A; 1981.

21. Welch F. Education in Production. Journal of Political Economy. 1970;28(1):35-59.

22. Nelson RR, Phelps ES. Investment in human technological diffusion and economic growth. American Economic Review. 1966;56.

23. Ibeawuchi II, Obiefuna JC, Ofoh MC, Matthews-Njoku EC, Ajaero JO. Productivity of Yam-Cassava based/Land-race legumes in intercropping systems. Life science Journal. 2007;5(1):80-86.

24. International Institute of Tropical Agriculture (IITA). Cassava: Production and processing, International Institute for Tropical Agriculture publication, Ibadan, Nigeria. 1990;4-10.

25. Odurukwe OS, Ikeorgu EJ. Effects of fertilizer and time of introduction of cassava in Yam/maize/cassava intercrop on component yield. Proceedings of the $9^{\text {th }}$ symposium of the International Society for Tropical Root Crops; 1991.

(c) 2013 Obasi et al.; This is an Open Access article distributed under the terms of the Creative Commons Attribution License (http://creativecommons.org/licenses/by/3.0), which permits unrestricted use, distribution, and reproduction in any medium, provided the original work is properly cited.

Peer-review history:

The peer review history for this paper can be accessed here:

http://www.sciencedomain.org/review-history.php?iid=203\&id=2\&aid=1173 